\title{
TOMASZ STEFANIUK
}

(Lublin)

\section{AL-KINDI I POCZĄTKI ARABSKIEJ TERMINOLOGII FILOZOFICZNEJ}

\section{Wprowadzenie}

Filozofia świata islamu zasługuje na uwagę co najmniej z kliku powodów; jednym z nich jest fakt, że uczeni islamscy umożliwili zachowanie na gruncie kultury muzułmańskiej istotnych elementów dorobku świata antycznego, grecko-rzymskiego. Najwybitniejsze zasługi w tej dziedzinie należy przypisać pierwszej instytucji naukowej świata islamu, tzw. Domowi Mądrości, którego kierownikiem był Hunajn ibn Ishak ${ }^{1}$ (Johannitus), tłumacz m.in. dzieł Platona i Arystotelesa ${ }^{2}$. Ruch tłumaczeniowy - w którym brali zresztą udział przedstawiciele rozmaitych narodów i wyznawcy różnych religii: m.in. Arabowie Syryjczycy, Koptowie, Persowie, chrześcijanie, muzułmanie i żydzi ${ }^{3}-\mathrm{w}$ istotny sposób przyczynił się do zachowania ciągłości kulturowej, w tym również ciągłości w dziedzinie refleksji filozoficznej. Owocem pracy uczonych działających w owym okresie były liczne osiągnięcia naukowe, przekazane następnie (pod koniec średniowiecza i na początku epoki nowożytnej) Europejczykom. Pisze o tym m.in. Wielgus:

Najwybitniejsi uczeni europejscy, najpierw, w XIII wieku, ze szkoły w Chartres, a potem wielcy uczeni ze szczytowego okresu rozwoju scholastyki, tacy zwłaszcza jak Albert Wielki, Tomasz z Akwinu i bardzo wielu innych, czerpali dosłownie

\footnotetext{
1 W niniejszym tekście zastosowano uproszoną transliterację z języka arabskiego.

2 Zob. Bieniek A., Starożytność w myśli arabskiej, Kraków 2003, s. 22-24.

3 Zajączkowski A., Avicenna - Abu Ali Ibn Sina, Warszawa 1953, s. 13-14.
} 
garściami nie tylko z greckiej spuścizny, przekazanej im przez muzułmanów, lecz także z dzieł uczonych islamskich, w tym z traktatów wszystkich perypatetyków muzułmańskich, a szczególnie z dzieł Awicenny i Awerroesa. (...) Każdy badacz średniowiecznej filozofii (...) łatwo stwierdza olbrzymi wpływ muzułmańskich filozofów na średniowiecznych filozofów chrześcijańskich ${ }^{4}$.

Uwadze historyka filozofii nie mogą również ujść oryginalne idee i koncepcje wypracowane przez islamskich filozofów ${ }^{5}$; wśród nich m.in. teoria jednego intelektu czynnego, w którym partycypować mieliby wszyscy ludzie („psychologia” Awerroesa ${ }^{6}$ ), dokonane przez Awicennę ${ }^{7}$ odróżnienie istnienia i istoty w bycie realnym, ujęcie bytu Boga jako bytu koniecznego, oraz zestawienie go z bytem tylko możliwym, tj. z wszelkim bytem poza-boskim (nadal Awicenna) ${ }^{8}$. Na uwagę zasługują również tzw. arabski arystotelizm, czy też inaczej mówiąc falsafa ${ }^{9}$ - stanowiący kompilację filozofii perypatetyckiej i wątków neoplatońskich, połączonych z elementami islamskimi - oraz jego najwybitniejsi reprezentanci: oprócz wspomnianego Awicenny m.in. al-Kindi oraz Al-Farabi.

Najznamienitsi filozofowie świata islamu najczęściej tworzyli w języku arabskim, mimo iż nierzadko nie byli etnicznymi Arabami ${ }^{10}$; w związku z tym badając historię filozofii islamskiej powinniśmy zwrócić uwagę na powstanie i rozwój arabskiej terminologii filozoficznej. Poszukując źródeł tejże terminologii należy uwzględnić specyfikę i rozwój języka arabskiego, a także oddziałanie tzw. literatury świeckiej uprawianej w omawianej epoce. Na ukształtowanie się arabskiej terminologii filozoficznej wpłynęły również pisma mutazylitów ${ }^{11}$ oraz z działalność wspomnianych już tłumaczy - przekładających naukową spuściznę staro-

4 Wielgus, Z obszarów średniowiecznej myśli islamskiej, żydowskiej i chrześcijańskiej, Płock 2002 , s. 22 .

5 Pisząc o filozofii islamskiej, a także o filozofach islamskich, nie mam na myśli tego, iż filozofia ta stanowiła „przedłużenie” islamskiej teologii, ponieważ najczęściej tak nie było. Określenie to oznacza po prostu filozofię uprawianą na gruncie kultury muzułmańskiej, korzystającą zarówno ze źródeł religijnych (m.in. Koran), jak i ze spuścizny filozofii greckiej.

6 Ibn Ruszda.

7 Ibn Sinę.

8 Co zostało zapożyczone przez chrześcijańską scholastykę podkreślającą znikomość człowieka i świata wobec Boga.

9 Określenie falsafa występuje m.in. na gruncie badań nad historią filozofii islamskiej uprawianych w językach arabskim i angielskim. Warto zauważyć, że pojęcie "arabski arystotelizm" jest nieco mylące, ponieważ poglądy al-Farabiego, Awicenny czy Awerroesa ukształtowały się nie tylko pod wpływem arystotelizmu, lecz również pod wpływem platonizmu i neoplatonizmu (szczególnie zaś neoplatońskich komentarzy do Arystotelesa); ponadto z wymienionych filozofów zaledwie jeden (Awerroes) był etnicznym Arabem, np. Awicenna był Persem.

10 Patrz: przyp. poprzedni.

11 Grupy nieortodoksyjnych teologów muzułmańskich odwołujących się również do spuścizny filozofii greckiej. 
żytności na język arabski. Na szczególną uwagę zasługuje traktat $O$ definicjach al-Kindiego ${ }^{12}$ - będący jednocześnie pierwszym słownikiem arabskich terminów filozoficznych.

\section{2. Źródła arabskiej terminologii filozoficznej}

Powstanie arabskiej terminologii filozoficznej wiązało się zarówno z tworzeniem nowych terminów, jak i z przenikaniem do ówczesnej arabszczyzny określeń obcych $^{13}$.

Warto zauważyć, iż nowe określenia zaczęły przenikać do języka arabskiego jeszcze przed tzw. okresem islamizacji - tj. przed okresem intensywnego budowania imperium muzułmańskiego w epoce Abbasydów. Wówczas to, jak pisze Danecki, „kultury, które znalazły się pod panowaniem arabskim, zaczęły wnosić do islamu [chodzi o kulturę islamu - przyp. T.S.] swój wkład, co w sposób oczywisty znalazło wyraz w przekształceniach języka" 14. Jak słusznie zauważa Afnan, „już słownictwo [klasycznego języka arabskiego ${ }^{15}$ - przyp. T.S.] zdradza obecność słów obcych" 16.

Nowe terminy przeniknęły do arabszczyzny m.in. z języków aramejskiego ${ }^{17}$ i perskiego, lecz również z greki - aczkolwiek oddziaływanie języka greckiego było znacznie mniejsze niż np. oddziaływanie języka aramejskiego. Większość określeń greckich, które w początkowym okresie weszły do języka arabskiego, weszło doń za pośrednictwem języka syryjskiego ${ }^{18}$. Zmiany te możliwe były dzięki kontaktom

12 Pełny tytuł: Risala al-kindi fi hudud al-aszia'i wa rusumiha (arab. Traktat Al-Kindiego o definicjach rzeczy oraz ich opisanie); zob. Abu Rida (ed.), Rasa'il al-kindi al-falsafijja, b.m.w. 1950 , s. $163-179$.

13 Mimo iż arabski jest (w porównaniu z innymi) językiem niesłychanie zachowawczym; zob. Danecki, Klasyczny język arabski, wyd. cyt., s. 15.

14 Tamże, s. 9.

15 Jeżeli chodzi o ewolucję języka arabskiego, wyróżnić można w pewnym uproszczeniu następujące główne etapy jego rozwoju: a) funkcjonowanie klasycznego języka arabskiego - między VI a VIII w. po Chr.; b) przekształcenie się języka klasycznego się w arabski język literacki, który (oprócz licznych dialektów) jest używany do dzisiaj.

16 Zob. Afnan S., Philosophical Terminology in Arabic and Persian, Leiden 1964, s. 9-13 i in.

17 Także języka semickiego; jak wiadomo, językiem tym posługiwał się Jezus Chrystus i jego uczniowie (po aramejsku spisane są niektóre fragmenty Starego Testamentu). Począwszy od ok. połowy pierwszego tysiąclecia przed Chr. aramejski pełnił rolę bliskowschodniego lingua franca; następnie rolę tę przejął właśnie język arabski.

18 Zob. tamże. Język syryjski (bądź syriacki): dialekt wschodnioaramejski, od VIII stulecia po Chr. nie używany w mowie, aczkolwiek utrwalił się jako język liturgiczny chrześcijaństwa bliskowschodniego (jest używany m.in. przez kościoły jakobicki, marionicki czy nestoriański). 
z ludami sąsiadującymi z Arabami ${ }^{19}$. W związku z powyższym warto wspomnieć między innymi o trójjęzycznych inskrypcjach syryjsko-grecko-aramejskich z Zabad, a także dwujezycznych, grecko-arabskich z Harran ${ }^{20}$; w Palmirze, w Syrii, element lokalnego dialektu stanowiły wyrażenia greckie, zaś oficjalne dokumenty przygotowywano zarówno w języku aramejskim, jak i w greckim. Również nabatejczycy $^{21}$ prawdopodobnie mówili po grecku, zaś na dworze Ghassanidów ${ }^{22}$ swobodnie spotykali się kupcy mówiący po arabsku oraz posługujący się językiem greckim $^{23}$.

Jest interesujące, że język arabski został wzbogacony o nowe określenia przede wszystkim dzięki wysiłkowi nie-Arabów: nie-arabskich muzułmanów, bądź też nie-arabskich obywateli państwa islamskiego, między innymi chrześcijan. Uczyli się oni nie tyle dialektów, co „czystego języka arabskiego” 24; jak pisze Danecki:

Nie był to język ponadplemienny, ale język olbrzymiego państwa: nowej nauki i literatury. Literatura z jednej strony kontynuowała dawną twórczość beduińską ${ }^{25}$, z drugiej zaś czerpała wzory z przekładów. Nauka w wyniku ruchu tłumaczeniowego przejęła dziedzictwo starożytności i hellenizmu. Gwałtowne przemiany znalazły wyraz przede wszystkim w leksyce wzbogacającej się o zapożyczenia i kalki. Stare słowa zyskały zupełnie nowe znaczenie ${ }^{26}$.

Poszukując źródeł arabskiej terminologii filozoficznej należy wyróżnić trzy główne gatunki uprawianej ówcześnie literatury ${ }^{27}$, które wpłynęły na kształtującą się w tamtej epoce terminologię filozoficzną: literaturę sensu stricte religijną, pisma mutazylitów, a także literaturę świecką - która oddziałała w zdecydowanie największym stopniu.

Jeżeli chodzi o wpływ literatury sensu stricto religijnej, był to, co oczywiste, przede wszystkim wpływ Koranu; Ksiega ta nie tylko uformowała fundamenty cywilizacji islamskiej, lecz również wyznaczyła i utrwaliła pewien kanon, jeżeli

\footnotetext{
19 Zob. Afnan, dz. cyt., s. 9.

20 Tamże.

21 Starożytny lud semicki, przybyły na tereny południowej Palestyny i południowej Jordanii z Płw. Arabskiego. W III stuleciu przed Chrystusem Nabatejczycy utworzyli królestwo ze stolicą w Petrze, a następnie w Bosrze. Mówiący po arabsku Nabatejczycy posługiwali się pismem aramejskim (korzystającym - podobnie jak język arabski - z alfabetu spółgłoskowego, abdżadu).

22 Lud arabski, wyznający (od VI w. po Chr.) chrześcijaństwo (w wersji monofizyckiej).

23 Zob. tamże.

24 Nie stanowiących rezultatu rozwoju klasycznego czy też literackiego języka arabskiego, lecz rozwijających się równolegle i synchronicznie; zob. Danecki, dz. cyt., s. 24.

25 Ograniczającą się do arabskiej poezji okresu przed-islamskiego; zob. Afnan, dz. cyt., s. 10.

26 Danecki, dz. cyt., s. 23.

27 Zob. Afnan, dz. cyt., s. 11-13.
} 
chodzi o język. W pracach tłumaczy przekładających na język arabski dzieła naukowe świata greckiego, jak również w literaturze świeckiej tamtej epoki, a następnie w nomenklaturze filozoficznej, odnajdujemy określenia pochodzące z Koranu; określenia owe często zyskiwały nowe znaczenie, jak również nową formę.

Na powstanie arabskiej terminologii filozoficznej wpłynęły również pisma mutazylitów - reprezentantów racjonalistycznego, nieortodoksyjnego nurtu w teologii muzułmańskiej, powstałego w VIII w. po Chr., korzystających z metod filozofii greckiej ${ }^{28}$; pisma te zajmowały miejsce pośrednie między pisarstwem sensu stricte religijnym a literaturą świecką omawianej epoki, zarówno jeżeli chodzi o styl, jak i o terminologię ${ }^{29}$. Jak zauważa Afnan, „mutazylici, którzy dobrze znali zarówno język teologii, jak i literaturę, ukuli pewne terminy filozoficzne dla własnych, partykularnych celów" 30. Co prawda niekiedy można mieć uzasadnione wątpliwości odnośnie do tego, czy pewne konkretne określenia rzeczywiście zostały po raz pierwszy użyte przez teologów mutazylickich czy też jedynie przez nich zaadaptowane (tak jest np. z arabskim określeniem al-'aql: rozum, intelekt) - tym niemniej mutazylici stworzyli pewien łatwo dający się wyodrębnić gatunek w literaturze tamtej epoki, który należy wziąć pod uwagę poszukując źródeł terminologii filozoficznej w języku arabskim.

Badając początki arabskiej terminologii filozoficznej nie sposób jednak nie zauważyć, iż dla jej powstania kluczowy okazał się wpływ literatury świeckiej; jak pisze Afnan:

Poszukiwanie źródeł arabskiej literatury filozoficznej, jak i arabskiej terminologii filozoficznej, prowadzi ostatecznie do literatury świeckiej. Istniały ważne przyczyny, dla których autorzy przekładów [chodzi o epokę tłumaczeń - przyp. T.S.] wybrali ją jako wzorzec w swych usiłowaniach zmierzających do przełożenia dzieł greckich na język arabski ${ }^{31}$.

W literaturze świeckiej omawianej epoki należy wyróżnić następujące gatunki: epistolografię, literaturę dworską oraz beletrystykę ${ }^{32}$.

\footnotetext{
28 Ujmując oddziaływanie teologii mutazylickiej z perspektywy historycznej należy dodać, iż ruch tłumaczeniowy zyskał szczególne wsparcie ze strony państwa szczególnie za panowania al-Ma'muna (813-833 po Chr.) oraz jego następców: al-Mu'tasima (833-842) oraz al-Watiqa (842-847). Wspomniani władcy wspierali teologię mutazylicką, korzystającą, jak wiadomo, z metod i pojęć filozofii greckiej - pośrednio bądź bezpośrednio przyczyniając się przez to do rozwoju filozofii. Sytuacja ta uległa zmianie za panowania al-Mutawakkila (847-861); poparł on ortodoksyjny islam, jednocześnie usiłując ograniczyć rozwój filozofii, którą postrzegał jako po prostu narzędzie teologii mutazylickiej.

29 Zob. Afnan, dz. cyt., s. 13.

30 Tamże.

31 Tamże, s. 14.

32 Zob. tamże, s. 11-12.
} 
Jeżeli chodzi o epistolografię, początków jej należy poszukiwać w działalności tzw. diwanów, tj. wysokich urzędów imperium muzułmańskiego - w których pracowali tzw. katibowie (od arab. kataba, pisać). Byli oni „ludźmi adabu”, czyli ogólnej kultury czy też wychowania - przez co należy rozumieć przestrzeganie odpowiednich norm moralnych ${ }^{33}$, znajomość religii, literatury etc. ${ }^{34}$ Katibowie stanowili wykształconą elitę tamtej epoki, najczęściej łącząc perskie lub syryjskie pochodzenie $z$ islamem ${ }^{35}$. Rozważając wpływ epistolografii na powstanie arabskiej terminologii filozoficznej należy zauważyć, iż część słownictwa spotykanego w ówczesnej prozie epistolarnej przeniknęła właśnie do owej terminologii ${ }^{36}$. Niejako na marginesie warto również wspomnieć o wpływie elementów kultury perskiej na świat islamu w epoce Abbasydów. Jak wiadomo, literatura świecka korzystała w omawianym okresie przede wszystkim ze wzorców irańskich (perskich); wynikało to zresztą między innymi z potrzeb polityczno-administracyjnych: po podbiciu irańskiego królestwa Sasanidów władcy islamscy dążyli do przyswojenia i wykorzystania irańskich metod zarządzania państwem. Ze wzorów perskich korzystali również pierwsi twórcy dzieł beletrystycznych, służących przede wszystkim rozrywce ${ }^{37}$. Istotne ogniwo łączące prozę świecką z działalnością tłumaczy, a także z rodzącym się właśnie pisarstwem filozoficznym, stanowiły dokonania Persa Ibn al-Muqaffa' $\mathrm{y}^{38}$, autora przekładu na język arabski Kailla wa dimna ${ }^{39}$ - dzieła uważanego za pierwsze wielkie osiągnięcie świeckiej literatury arabskiej; uczony ów przełożył ponadto na arabski (najprawdopodobniej z języka średnio-perskiego, tj. z Pahlawi) fragmenty Organonu Arystotelesa, prawdopodobnie znał on również dobrze arystotelesowską etykę ${ }^{40}$. Warto także zwrócić uwagę na listy wymieniane rzekomo między Arystotelesem a Aleksandrem Macedońskim - w istocie pseudo-arystotelesowskie - które zachowały się w bibliotekach istambulskich ${ }^{41}$; poprzedziły one większość dzieł poświęconych omówieniu filozofii greckiej, jakie ukazały się w interesującym nas okresie tłumaczeń ${ }^{42}$.

33 Arab. słowo adab oznacza (dobre, właściwe) zachowanie; w badaniach nad islamem oznacza ogólną kulturę muzułmańską; zob. np. Danecki, Podstawowe wiadomości o islamie, wyd. cyt., t. $1 .$, s. 250 .

34 Termin adab oznacza również literaturę piękną (tzw. literatura adabowa); zob. np. Danecki, tamże, t. 1., 246.

35 Zob. tamże; jak widać, do funkcjonowania i wzrostu kalifatu przyczyniali się również nie-Arabowie (zob. również przykład Persa Ibn al-Muqaff'y - dalej).

36 Zob. Afnan, dz. cyt., s. 12.

37 Zob. tamże.

38 Właśc. Abu-Muhammad Abd-Allah Ruzbih ibn Daduja (zm. ok. 765 po Chr.).

39 Zob. Krzyżowski J., Kalila i Dimna, Warszawa 2006.

40 Zob. Afnan, dz. cyt., s. 18.

41 Zob. tamże.

42 Zob. tamże. 
Powyższe uwagi ukazują wyraźnie, iż arabska terminologia filozoficzna została w epoce tłumaczeń utworzona przede wszystkim przez osoby nie będące wykształconymi filozofami - tym niemniej majace (za pośrednictwem kultury perskiej, syryjskiej, ewentualnie nauki chrześcijańskiej etc.) styczność z filozofią grecką. Autorzy przekładów ${ }^{43}$ praktycznie nie ukuli wielu nowych terminów, tym niemniej w znaczący sposób przyczynili się do jej rozwoju, ponieważ faktycznie podejmowali decyzje odnośnie do tego, jakie arabskie ekwiwalenty mają być używane dla zastąpienia określeń greckich.

Jeżeli chodzi o metody tworzenia nowych terminów naukowych w języku arabskim w epoce tłumaczeń, wymienić można następujące ${ }^{44}$ : nadawanie nowych znaczeń i skojarzeń zwykłym określeniom z języka potocznego, a przez to - nadawanie im funkcji technicznych terminów filozofii bądź logiki (neologizmy znaczeniowe); stosowanie zapożyczeń z różnych języków, które niekiedy pozostawiano $\mathrm{w}$ formie oryginalnej, niekiedy zaś odpowiednio arabizowano; ukucie nowych terminów ze źródeł oryginalnych, w zgodności z zasadami morfologii (neologizmy słowotwórcze). Nie ulega wątpliwości, iż większość nowych określen, wykorzystywanych następnie jako techniczne terminy filozofii, została utworzona w oparciu o wyżej wymienione metody.

Jest interesujące, iż sami filozofowie świata islamu dość późno zdali sobie sprawę z niedostatków nowoutworzonej arabskiej terminologii filozoficznej; zresztą ich stosunek do tejże terminologii nie zawsze był taki sam: al-Kindi i al-Farabi, pierwsi wybitni filozofowie islamscy, nie odważyli się jeszcze skrytykować ani nawet dogłębniej zanalizować dorobku tłumaczy, a także ich wpływu na język filozofii. Prowadziło to rzecz jasna do nieporozumień i błędów, czego przykład stanowić może próba zharmonizowania poglądów Platona i Arystotelesa, podjęta właśnie przez al-Farabiego. Również najwybitniejszy filozof świata islamu, Awicenna (nie znający ani greckiego ani syryjskiego) nie mógł otwarcie zarzucać działającym w IX wieku tłumaczom popełniania istotnych błędów. Dopiero Awerroes (XII stulecie po Chr.) w swoim komentarzu do Arystotelesowskiej $\mathrm{Me}$ tafizyki odważył się zakwestionować jakość dzieła tłumaczy - cytując w swych pracach fragmenty pochodzące nawet z trzech różnych przekładów źródłowych tekstów greckich ${ }^{45}$.

43 Autorzy przekładów zwykle byli uczonymi kształconymi w klasztorach (monofizyckich i nestoriańskich) bądź też w szkołach przyklasztornych; najczęściej odebrali oni również dobre wykształcenie klasyczne. Jeżeli chodzi o języki, jakimi posługiwali się tłumacze, warto podkreślić, iż ich ojczystym językiem był najczęściej syryjski; tym niemniej używany był przez nich również arabski - był to bowiem język, jakim na co dzień posługiwano się w państwie islamskim.

44 Zob. Afnan, dz. cyt., s. 28.

45 Zob. tamże, s. 23-24. 


\section{Al-Kindi i jego traktat $O$ Definicjach}

Abu Jusuf Ja'qub ibn Ishaq Al-Kindi, w zlatynizowanej wersji jego imienia Alkindus - żyjący ok. 801-873 po Chr. uczony, zajmujący się wieloma dziedzinami wiedzy, m.in. filozofią, medycyną, farmakologią, astronomią i matematyką - był w przeciwieństwie do wielu kolejnych wybitnych filozofów świata islamu, chociażby al-Farabiego czy Awicenny, etnicznym Arabem.

W epoce, w której przyszło mu żyć i działać, świat islamu - w którym język arabski od początku pełnił funkcję języka międzynarodowego, łączącego ${ }^{46}$ różne elementy etniczne muzułmańskiej ummy ${ }^{47}$ - po raz pierwszy spotkał się z filozofią, a także z innymi „obcymi naukami”, zapisanymi między innymi w językach greckim i syryjskim. Opracowanie arabskiej terminologii naukowej, w tym również terminologii filozoficznej, stało się koniecznością. Jak pisze Kennedy-Day:

Ponieważ al-Kindi był pierwszym filozofem piszącym po arabsku, zmierzył się z problemami związanymi z wyrażeniem technicznych terminów [filozofii przyp. T.S.], które to problemy nie były już udziałem jego następców [na polu filozofii islamskiej - przyp. T.S.]. Kiedy Arabowie zaczęli tłumaczyć teksty greckie (...), język arabski nie zawierał jeszcze technicznej terminologii [filozoficznej przyp. T.S.], z pomocą której można byłoby wyrazić koncepcje filozoficzne ${ }^{48}$.

Najważniejszym dziełem al-Kindiego poświęconym opracowaniu terminologii filozoficznej w języku arabskim jest traktat zatytułowany Risala al-kindi fi hudud al-aszja'i wa rusumiha ${ }^{49}$ (arab. Traktat Al-Kindiego o definicjach rzeczy oraz ich opisanie, dalej jako: $O$ definicjach ${ }^{50}$. Zajmuje on w zbiorowym wydaniu filozoficznych pism Alkindusa ${ }^{51}$ drugie miejsce, zaraz po najważniejszym zachowanym filozoficznym dziele arabskiego uczonego, jakim jest Kitab al-kindi fi falsafa al-ula (arab. Ksiega Al-Kindiego o filozofii pierwszej) ${ }^{52}$. Według redaktora nowożytnego wydania filozoficznych traktatów Alkindusa, Abu Ridy, traktat $O$ definicjach po-

\footnotetext{
46 Chociażby ze względu na Koran i hadisy zapisane właśnie w języku arabskim.

47 Określenie umma (arab. pochodzenia) oznacza po prostu całą (ponadnarodową) wspólnotę islamską; zob. m.in. Koran 3:110.

48 Kennedy-Day K., Limits of the Words, Londyn 2003, s. 19.

49 Warto zauważyć, iż arabskie słowo hudud oznacza nie tylko definicję, lecz również granicę (czegoś) - tutaj: granice prawidłowego pojmowania określeń, którymi posługujemy się w uprawianiu nauki, filozofii; zob. Kennedy-Day, tamże.

50 Zob. al-Kindi, dz. cyt., s. 163-179.

51 Zob. przyp. 12.

$52 \mathrm{~W}$ pracy tej niewątpliwie najdokładniej zaprezentowane zostały kindiańska epistemologia i metafizyka.
} 
winien być traktowany jako klucz do właściwego zrozumienia kolejnych dzieł arabskiego filozofa ${ }^{53}$.

O znaczeniu traktatu $O$ definicjach Al-Kindiego świadczy przede wszystkim istotne miejsce, jakie zajmuje on w historii nauki islamskiej, a zwłaszcza w historii islamskiej filozofii ${ }^{54}$. Mnożna wymienić jeszcze kilka prac poświęconych omówieniu arabskiej terminologii filozoficznej, takich jak chociażby Mufatih al-'ulum (arab. Klucze nauk) al-Chuwarizmiego ${ }^{55}$, Kitab at-ta'rifat (arab. Ksiega definicji) Al-Dżurdżaniego ${ }^{56}$ czy Risala al-hudud (arab. Traktat o definicjach) Ibn Siny (Awicenny); tym niemniej to właśnie al-Kindi jako pierwszy filozof świata islamu podjął się trudu opracowania tejże terminologii. Wspomniany traktat Alkindusa $O$ definicjach był pierwszym słownikiem filozoficznym, a jednocześnie w ogóle pierwszym słownikiem, jaki ukazał się w świecie islamu - przynajmniej z tych, które dochowały się do naszych czasów ${ }^{57}$.

Należy zauważyć, iż Al-Kindi był silnie powiązany ze środowiskiem mutazylitów ${ }^{58}$, tj. działającą w tamtym czasie grupą nieortodoksyjnych teologów islamskich, którzy dla uzasadnienia własnych poglądów korzystali z osiągnięć filozofii greckiej. Nie oznacza to jednak, iż sam autor traktatu $O$ definicjach był teologiem, przeciwnie - Alkindusa należy uznać za pierwszego filozofa świata islamu, który korzystał zarówno z islamskiej tradycji religijnej, jak i z filozofii greckiej.

\footnotetext{
53 Zob. al-Kindi, dz. cyt., s. 180.

54 Pisząc o islamskiej nauce - w tym również o islamskiej filozofii - nie mam na myśli wyłącznie nauk religijnych uprawianych w świecie islamu (teologia, szariat, fikh etc., całkowicie zgodnych z ortodoksyjnym islamem, czy też zeń wynikających), lecz wszystkie dziedziny wiedzy, jakimi zajmowano się w świecie islamu.

55 Al-Chuwarizmi (zm. ok. 850 r.): wybitny matematyk, astronom i geograf perskiego pochodzenia, podobnie jak al-Kindi związany z bagdadzkim Domem Mądrości - pierwszą znaczącą instytucją naukową świata islamu. Al-Chuwarizmi znany jest $\mathrm{z}$ wprowadzenia pochodzącego $\mathrm{z}$ Indii dziesiętnego systemu liczenia i pozycyjnego systemu zapisu liczb; prace al-Chuwarizmiego umożliwiły również wprowadzenie pojęcia zera, ułamków, opisane zostały w nich również funkcje sinus i tangens. Termin „algebra” został utworzony od arabskiego al-dżabr, którym to określeniem posługiwał się uczony, zaś termin „algorytm” pochodzi od zlatynizowanej wersji jego imienia.

56 Zob. Abu Rida, dz. cyt., s. 164.

57 Wcześniej, jeszcze przed kindiańskim traktatem $O$ definicjach, ukazała się Kitab al-hudud (arab. Ksiega definicji), napisana przez gramatyka al-Farra'ę - m.in. komentatora Koranu, zm. w 822 po Chr.; większość jego prac nie dotrwała do naszych czasów. Zob. Calder N., Mojaddedi J. A., Rippin A., Classical Islam: A Sourcebook of Religious Literature, Londyn 2003, s. 208.

58 Mutazylici to jedna ze szkół tzw. kalamu (od arab. kalam, mowa), czyli tzw. islamskiej teologii dialektycznej, wzgl. spekulatywnej - odróżnianej od teologii dogmatycznej, zwanej usul ad-din, usiłującej jedynie w odpowiedni sposób wyjaśnić zasady wiary i negatywnie zapatrującej się na wszelkie spekulacje dotyczące objawienia. Niewątpliwie najważniejszym nurtem kalamu był właśnie mutazylizm (w epoce al-Kindiego, tj. w IX w. po Chr.). Inna arab. nazwa kalamu to 'ilm al-kalam (dosł. wiedza kalamu); uczony zajmujący się kalamem to mutakallim. Zob. Danecki, Podstawowe wiadomości o islamie, wyd. cyt., t. 1, s. 160-208.
} 
Wykazanie owego podwójnego powiązania ideowego, czy tė̇ owego podwójnego źródła inspiracji - decydującego zresztą o oryginalności i niepowtarzalności całej filozofii islamskiej - powinno opierać się na dokładniejszym omówieniu wpływu zarówno teologii islamskiej, jak i filozofii greckiej na treść traktatu $O$ definicjach.

A. Oddziałanie teologii islamskiej: O wyraźnym powiązaniu treści kindiańskiego traktatu $O$ definicjach z teologią islamską decydują między innymi: obecność w tekście traktatu terminów istotnych dla islamskiej refleksji teologicznej; występowanie w traktacie terminów wywodzących się wprost z Koranu; wpływ teologii islamskiej na treść definicji niektórych terminów zawartych w omawianym traktacie.

Jeżeli chodzi o określenia istotne nie tylko dla rozważań filozoficznych, lecz również dla teologii - zaprezentowane przez Alkindusa w omawianym traktacie $O$ definicjach - są to m.in. terminy następujące: al-'aql (arab. umysł, intelekt), an-nafs (dusza, jaźń), al-ibda' (creatio ex nihilo, stworzenie świata z niczego), as-sura (forma, kształt), al-'amal (praca, działanie), al-irada (wola), al-mahabba (miłość), al-wahid (jeden), al-'ilm (wiedza), as-sidq (prawda), al-hikma (mądrość), al-insanijja (bycie człowiekiem, człowieczeństwo, natura ludzka). Za określenia szczególnie istotne z punktu widzenia islamskiej teologii należałoby uznać al-ibda oraz al-wahid (arab. Jeden - jedno z tzw. najpiękniejszych imion Boga obecnych w Koranie ${ }^{59}$ ); warto zauważyć, iż drugi z wymienionych terminów pojawia się również w najważniejszej z zachowanych prac filozoficznych al-Kindiego - Księdze o filozofii pierwszej, pełniąc w owej pracy niezwykle ważną rolę ${ }^{60}$.

Jak to już zostało zaznaczone, w kindiańskim traktacie $O$ definicjach odnajdujemy również określenia filozoficzne zdefiniowane pod wpływem tradycji islamskiej. Alkindus określa na przykład poznanie zmysłowe jako „poznawanie przez duszę obrazów” 61, zaś rozmyślanie (refleksję) jako „skłonność duszy” 62 - co wiązało się z odrzuceniem przezeń materialistycznej koncepcji człowieka. Te i inne przykłady świadczą o wybieraniu przez al-Kindiego tych filozoficznych idei, które były do zaakceptowania w kulturze zdominowanej przez myśl religijną: islam wytworzył pewien całościowy światopogląd i przynajmniej początkowo uprawianie

59 Koran zawiera 99 tzw. najpiękniejszych imion Boga (arab. al-asma' al-husna), z filozoficznego i teologicznego punktu widzenia stanowiących jednocześnie Boże atrybuty; są to m.in. Miłosierny, Litościwy, Wszechmocy, Wszechwiedzący, Stwórca etc. Setnym imieniem jest Allach (arab. Bóg Jedyny).

$60 \mathrm{~W}$ dziele tym al-Kindi prezentuje idę al-wahid al-haqq: Prawdziwie Jednego - zakorzenioną zarówno w islamskiej teologii, jak i w filozofii greckiej, szczególnie w arystotelizmie i neoplatonizmie.

61 Zob. al-Kindi, dz. cyt., s. 167.

62 Zob. tamże, s. 168. 
filozofii jako takiej możliwe było jedynie w ramach owego światopoglądu ${ }^{63}$. Analogiczną uwage można notabene sformułować w odniesieniu do początków filozofii chrześcijańskiej i żydowskiej, także rozwijających czy tė̇, co najmniej, uzasadniających stanowisko religijne - przynajmniej w początkowym okresie funkcjonowania refleksji filozoficznej. Jeżeli chodzi o al-Kindiego, wybrał on te idee filozoficzne, które mogły być uzgodnione z islamem, a w każdym razie nie stały z nim w sprzeczności: przede wszystkim istotne elementy arystotelizmu, lecz również idee proweniencji platońskiej, neoplatońskiej czy też stoickiej (zwłaszcza etyka) ${ }^{64}$.

B. Oddziałanie tradycji filozoficznej: O powiązaniu treści kindiańskiego traktatu $O$ definicjach z filozofią grecką świadczą przede wszystkim: zdefiniowanie w omawianym traktacie terminu „filozofia” i poświęcenie mu przez Alkindusa szczególnej uwagi; znacząca liczba definicji terminów ściśle filozoficznych (technicznych terminów filozofii), występujących w traktacie; obecność terminów stanowiacych przekształcenia greckich określeń filozoficznych; ścisłe powiązanie filozofii al-Kindiego z filozofią Arystotelesa; powiązanie z ideami wypracowanymi przez innych filozofów greckich, zwłaszcza przez platoników, neoplatoników, a także stoików.

Jeżeli chodzi o definicje określeń pełniących funkcję technicznych terminów filozofii, stanowią one większość terminów zaprezentowanych w traktacie; spośród wszystkich terminów zebranych w omawianym traktacie zaledwie dwudziestu 65 nie można powiązać z filozofią.

W omawianym traktacie al-Kindiego spotykamy się również z terminami stanowiącymi przekształcenia greckich określeń filozoficznych, takimi jak al-hajula (arab. materia pierwsza, utworzone od greckiego hyle), al-istaqas (arab. element, utworzony od grec. stocheion), a także al-falsafa (arab. filozofia). Ich obecność w traktacie świadczy po pierwsze o silnych inspiracjach ze strony filozofii greckiej, po wtóre o próbach samodzielnego opracowania własnej (arabskiej) terminologii

63 Z czasem pojawili się (nieliczni zresztą) filozofowie, którzy negowali ów islamski światopogląd; przykład stanowi działalność ar-Raziego (w wersji zlatynizowanej Rhazesa, IX-X w. po Chr.).

64 Sytuacja ta nie odbiegała zatem zasadniczo od początków filozofii chrześcijańskiej w okresie patrystycznym, kiedy to tzw. Ojcowie Kościoła korzystali z dorobku tych filozofów (przede wszystkim Platona, Filona, Plotyna i innych neoplatoników), których idee nie przeczyły fundamentom wiary chrześcijańskiej.

65 Są to m.in. terminy takie jak: al-dizidr (pierwiastek - w rozumieniu nauk matematycznych), ad-darb (mnożenie), al-qisma (dzielenie), 'ilm an-nadżum (astronomia), al-intina' (giętkość, elastyczność), al-baruda (zimno, chłód), al-Jarrara (gorąco, ciepło), ar-ra’iha (woń, zapach), ar-ratuba (wilgotność, wilgoć), ad-daghad (ściśnięcie), at-tibb (medycyna), al-kasr (pęknięcie, złamanie) i inne. Warto zauważyć, iż al-Kindi był jednym z najwybitniejszych lekarzy swoich czasów. Z kolei obecna na kartach omawianego traktatu definicja terminu al-iqa (rytm) przypomina, iż w spektrum zainteresowań badawczych al-Kindiego (podobnie jak później al-Farabiego) znajdowała się również muzyka. 
filozoficznej. Te i inne terminy (między innymi arab. namus, stanowiące przekształcenie grec. nomos, prawo) zostały utworzone poprzez zastosowanie transkrypcji z tłumaczonego tekstu greckiego. Rozbieżność między terminami wynikała prawdopodobnie z tego, że tłumaczeń dokonywano (przynajmniej niekiedy) za pośrednictwem języka syryjskiego, co mogło wpływać na zmianę formy, jaką przybierało nowe słowo, bądź też wiązać się ze zmianami dotyczącymi sposobu wokalizowania danego słowa ${ }^{66}$.

$\mathrm{Na}$ wyjątkową uwage zasługują bardzo ścisłe związki filozofii al-Kindiego z myślą Arystotelesa, w tym również z rozmaitymi interpretacjami dorobku filozoficznego Stagiryty - dokonywanymi między innymi w duchu platońskim, neoplatońskim, naturalistycznym etc. ${ }^{67}$ Jak wiadomo, od czasów Andronikosa z Rodos - dziesiątego scholarchy, tworzącego w I w. przed Chr., a zarazem słynnego wydawcy zbiorowej edycji pism Arystotelesa - rozpoczyna się ruch komentatorski, majacy za zadanie interpretowanie myśli Arystotelesa. Począwszy od III w. po Chr., jak pisze Leśniak, „myśli perypatetyckiej zagraża nowe niebezpieczeństwo: (...) zaczyna się ją interpretować z pozycji platonizmu i neoplatonizmu" 68 . Jednym z najwybitniejszych komentatorów Arystotelesa, działających w tamtym okresie, był Porfiriusz (III-IV w. po Chr.); był on jednocześnie redaktorem i wydawcą Plotyńskich Ennead oraz autorem tzw. Isagogi, czyli wstępu do arystotelesowskich Kategorii. Dzieło Porfiriusza kontynuowali między innymi najwybitniejsi komentatorzy Arystotelesa z VI wieku: Symplicjusz, Dawid Armeńczyk oraz Jan Filoponos (490-570 po Chr.), zwany również Janem Gramatykiem lub Janem Aleksandryjskim. Warto zaznaczyć, iż niektóre elementy filozofii al-Kindiego między innymi obrona idei Bożego stworzenia, a jednocześnie próby obalenia tezy (arystotelesowskiej proweniencji) o odwiecznym istnieniu świata - przywodzą na myśl właśnie poglądy głoszone przez Jana Gramatyka ${ }^{69}$.

66 Jest to opinia Afnana; zob. tenże, dz. cyt., s. 27. Jak wiadomo, w językach z grupy semickiej obowiązują pewne szczególne zasady dotyczące wokalizacji tekstu pisanego, co wiąże się między innymi (np. w języku arabskim) z wokalizowaniem niezaznaczonych w tekście pisanym samogłosek.

67 Kwestia recepcji myśli Arystotelesa po jego śmierci - a także opracowywania na tej bazie poglądów nowych, nieznanych w gruncie rzeczy samemu autorowi Metafizyki-stanowi osobne, niewątpliwie interesujące badawczo zagadnienie, które jednak nie może stać się tutaj, ze względu na charakter niniejszej pracy, przedmiotem szczegółowych analiz. Nt. interpretacji i przekształceń filozofii Arystotelesa zob. np. Leśniak K., Arystoteles, Warszawa 1989, s. 116-120.

68 Tamże.

69 Łączącego, jak zauważa Leśniak, „utopioną w komentarzach naukę Arystotelesa” z treściami biblijnymi; zob. tamże, s. 118. Niejako na marginesie warto zaznaczyć, iż również sam al-Kindi dał się poznać jako autor komentarzy do dzieł Stagiryty - dokładniej mówiąc, komentarzy do arystotelesowskich Analityków pierwszych oraz O dowodach sofistycznych, a zatem pism poświęconych logice; pozostawił po sobie także skrótowe opracowanie Poetyki; zob. Kennedy-Day, dz. cyt., s. 30. 
Analiza traktatu $O$ definicjach uwidacznia silne związki filozofii al-Kindiego z myślą arystotelesowską. Świadczy o nich chociażby sam zamiar poprawnego zdefiniowana najważniejszych terminów filozoficznych. Trudno nie zgodzić się ze stwierdzeniem, iż sam Arystoteles kładł szczególny nacisk na poprawne definiowane terminów naukowych. Wynikało to przede wszystkim z jego wyrażonego w Analitykach wtórych przekonania, iż natura wiedzy pierwotnej ${ }^{70}$ jest dwojakiego rodzaju: jest mianowicie wiedzą o faktach, bądź też wiedzą o znaczeniu słów - z związku z czym niezbędnym jest precyzyjne opracowanie znaczeń wszelkich określeń, jakimi posługujemy się uprawiając naukę ${ }^{71}$. Innymi słowy, to właśnie od definicji powinna zaczynać się wszelka wiedza; badania przygotowawcze, skupione wokół definicji, powinny prowadzić (ostatecznie) do wykrycia istoty rzeczy ${ }^{72}$.

Jak to już zostało wspomniane, kindiański traktat $O$ definicjach prezentuje i omawia wiele technicznych terminów filozofii; wpływ myśli arystotelesowskiej na treść omawianego uwidacznia już pierwsza definicja - definicja terminu al-'illa al-ula (arab. pierwsza przyczyna):

Pierwsza przyczyna - to, co stwarza, co czyni absolutnie wszystko, [zaś samo - przyp. T.S.] nie porusza się ${ }^{73}$.

Jak widać, definicja ta zawiera w gruncie rzeczy streszczenie poglądów Arystotelesa zawartych w Fizyce, w której to grecki filozof poddaje analizie problem ruchu: każdy przedmiot fizyczny albo porusza inny przedmiot albo sam jest poruszany - wyjąwszy Pierwszego Nieruchomego Poruszyciela, do którego wszystko dąży i który wprawia wszystko ruch ${ }^{74}$. Oprócz definicji pierwszej przyczyny w omawianym traktacie odnajdujemy jeszcze wiele innych definicji, których treść świadczy o silnym oddziaływaniu filozofii Arystotelesa na al-Kindiego; między innymi następujące: at-tabi'a (natura), al-hajula (materia), as-sura (forma), al-fi'l (akt, działanie), al-dżawhar (substancja), al-kammijja (ilość), al-kajfijja (jakość), az-zaman (czas), al-makan (miejsce), al-'ilm (wiedza), as-sidq (prawda), al-kadhb (fałsz), al-'ilall at-tabi'jja arba' (dosł. cztery przyczyny naturalne), al-hikma (mądrość), al- ‘iqqa (wstrzemięźliwość, cnotliwość), al-fada’il (cnoty) ${ }^{75}$.

70 Z której to poprzez wnioskowanie możemy dalej zyskiwać pewną wiedzę.

71 Zob. Leśniak, dz. cyt., s. 112.

72 Zob. tamże, s. 114.

73 Al-Kindi, dz. cyt., s. 165.

74 Zob. Stownik filozofii, Hartman J. (red.), Kraków 2004, s. 268. Zob. również: Arystoteles, Fizyka, ks. VII, rozdz. 5 .

75 Zob. również tab. 1. 
Definicje tych terminów przedstawione w traktacie al-Kindiego ukazują silny wpływ arystotelizmu. Na przykład jeżeli chodzi o naturę, według Alkindusa stanowi ona „początek ruchu i ustanie ruchu (...)" 76; analogicznie zapatruje się na to Arystoteles: według niego każdy element natury zawiera w sobie zasadę ruchu i spoczynku ${ }^{77}$. Z kolei o materii al-Kindi pisze, iż ,jjest to siła stworzona do udźwignięcia formy, sama stanowiąca przedmiot oddziaływania” 78; arabski filozof wyraża w ten sposób hylemorfizm (w każdym bycie konkretnym można wyróżnić formę i materię), stanowiący jedno z fundamentalnych pojęć metafizyki Arystotelesa $^{79}$.

Oddziaływanie metafizyki Arystotelesa odnajdujemy także w pozostawionych przez al-Kindiego definicjach formy i substancji:

Forma - coś, przez co dana rzecz jest tym, czym jest ${ }^{80}$.

Substancja - jest to coś istniejącego samo przez się [arab. qa'im bi-nafsih - przyp. T.S.]; i jest ona nośnikiem dla akcydensów ${ }^{81}$ [arab. hamil li-la'rad przyp. T.S.]; jej bycie sobą nie zmienia się [arab. lam tataghjjar datijjatuh przyp. T.S.] ${ }^{82}$.

O wpływie filozofii Arystotelesa na al-Kindiego świadczą również, między innymi, definicja przyczyny ${ }^{83}$, definicje niektórych wymienionych przez Arystotelesa kategorii ${ }^{84}$, jedna $\mathrm{z}$ podanych $\mathrm{w}$ omawianym traktacie definicji filozofii ${ }^{85}$, a także definicje wiedzy, prawdy i fałszu:

\footnotetext{
76 Zob. al-Kindi, dz. cyt., s. 165.

77 Zob. Leśniak, dz. cyt., s. 53.

78 Zob. al-Kindi, dz. cyt., s. 166 .

79 Zob. Leśniak, dz. cyt., s. 48-49.

80 Al-Kindi, tamże.
}

81 Inaczej: przypadłości, cech akcydentalnych - tj. takich cech danej substancji, bez których jest ona nadal tą samą substancją.

82 Tamże.

83 Przyczyna to „to, przez co istnieje rzecz”; zob. Al-Kindi, tamże, s. 169.

84 Jak wiadomo, Arystoteles pragnął rozwiązać aporie wynikające z filozofii Heraklita i Parmenidesa - według Heraklita prawdziwy byt jest zmienny z natury (wariabilizm), z kolei według Parmenidesa byt jest niezmienny, stały z natury. Arystoteles wymienił w swoim traktacie Kategorie dziesięć kategorii, tj. podstawowych sposobów bytowania jednego i tego samego bytu. Są to: substancja, ilość, jakość, stosunek, miejsce, czas, położenie, stan-dyspozycja, działanie oraz doznawanie. Zob. tenże, Cat., 1 b 25; zob. także: O duszy [410 a 13-15] oraz Topiki [103 b 20]; podaję za Powszechna Encyklopedia Filozofii, zob. URL = 〈http://ptta.pl/pef/pdf/k/kategorie.pdf $\rangle$. Niejako na marginesie warto zauważyć, że u Alkindusa pojawia się - jako neologizm - określenie al-qatighurijat (arab. kategorie), utworzony poprzez przekształcenie odpowiednika greckiego. Oprócz tego w języku arab. występuje określenie al-maqulat, również oznaczające arystotelesowskie kategorie.

85 Jest to, dokładniej mówiąc, ostatnia, szósta definicja filozofii przedstawiona w omawianym traktacie (oznaczona arabską literą ha); zob. al-Kindi, dz. cyt., s. 172-173. jak pisze arabski 
Wiedza - poznanie rzeczy zgodnie z ich prawdziwością.

Prawda - wypowiedź pozytywna [tj. potwierdzająca istnienie - przyp. T.S.] o tym, co jest, oraz negatywna [negująca istnienie - przyp. T.S.] o tym, czego nie ma $(\ldots)$.

Fałsz - wypowiedź pozytywna [potwierdzająca istnienie - przyp. T.S.] o tym, czego nie ma, oraz negatywna [negująca istnienie - przyp. T.S.] o tym, co jest $^{86}$.

W poglądach zawartych w kindiańskim traktacie $O$ definicjach odnajdujemy również wpływ etyki Arystotelesa ${ }^{87}$; należy między innymi zwrócić uwage na zbieżność pewnych fragmentów omawianego traktatu z arystotelesowską doktryną złotego środka, przedstawioną w Etyce nikomechejskiej. Zgodnie z ową koncepcją cnoty etyczne ${ }^{88}$ nakazują unikanie w postępowaniu wszelkich skrajności, jednocześnie wzywając do trzymania się środka: punktu pomiędzy dwoma ekstremami niedostatkiem i nadmiarem. Na wyraźny związek z arystotelesowską doktryną złotego środka wskazuje między innymi definicja terminu „cnoty” (arab. al-fada'il) ${ }^{89}$. Jak pisze al-Kindi, w związku z omawianiem cnót można mówić o dwóch skrajnościach; „pierwsza z nich pochodząca od przesady [arab. al-ifrat-przyp. T.S.], kolejna zaś od niedostatku [arab. at-taqsir-przyp. T.S.] (...)" 90. W kolejnym fragmencie traktatu $O$ definicjach al-Kindi omawia odwagę, prezentując ją oczywiście jako cnotę:

A jeżeli chodzi o ujęcie przez filozofię umiarkowania, (...) to mamy na myśli pewne umiarkowanie dobrej natury [człowieka - przyp. T.S.] (...); występek wobec

filozof, „,jeżeli chodzi o samą istotę filozofii, to owa istota jest taka, że filozofia jest wiedzą dotyczącą wszystkich rzeczy wiecznych [arab. 'ilm al-aszja' $i$ al-abdijja - przyp. T.S.], ich rzeczywistości oraz ich przyczyn, na tyle, na ile jest to w mocy człowieka"; zob. dz. cyt., s. 173. Podobny pogląd wyraża Arystoteles w swej Metafizyce, pisząc, iż „mędrzec (filozof) musi posiadać wiedzę możliwie o wszystkich rzeczach, mimo iż nie będzie posiadał wiedzy o każdej poszczególnej rzeczy. Po wtóre mędrcem jest ten, kto może poznać trudne rzeczy, niełatwe do poznania dla człowieka (...)." Zob. Arystoteles, Metafizyka, ks. A, 982 a 5 (podaję za: Leśniak, dz. cyt., s. 145).

86 Al-Kindi, tamże, s. 169.

87 Warto zauważyć, iż rozważania etyczne były tym, co w początkach myśli muzułmańskiej łączyło ortodoksyjnych teologów z uczonymi w ten czy w inny sposób zainteresowanymi filozofią; owe wspólne (przynajmniej częściowo) zainteresowania prawdopodobnie znacząco przyczyniły się do rozwoju filozofii w świecie islamu w jej początkowym okresie.

88 Jak wiadomo, Arystoteles wyróżniał również cnoty dianoetyczne, tj. rozumowe, których celem jest poznanie (celem cnót etycznych jest działanie praktyczne); według autora Etyki nikomachejskiej cnoty etyczne podporządkowane są dianoetycznym.

89 Definicję tę poprzedza definicja pojęcia „cnoty ludzkie” [arab. al-fada'il al-insanijja] - w której to al-Kindi wyróżnia cnoty związane z wnętrzem (charakterem, duszą) człowieka oraz, po drugie, te cnoty, które - jak np. hojność - uzewnętrzniają się. Zob. al-Kindi, dz. cyt., s. 177.

90 Tamże, s. 178. 
umiarkowania wiąże się [jeżeli chodzi o odwagę - przyp. T.S.] z dwoma przeciwstawnymi sytuacjami: pierwsza $\mathrm{z}$ nich pochodzi od nieumiarkowania i jest to ryzykanctwo [arab. at-tahawwur - przyp. T.S.] i szalona odwaga [arab. al-hawadizprzyp. T.S.], a jeżeli chodzi o kolejną, to bierze się ona z pewnego niedostatku, i jest to tchórzostwo [arab. al-dizubn-przyp. T.S. ${ }^{91}$.

O związkach filozofii al-Kindiego z etyką Arystotelesa - utożsamiającego szczęście z istotą człowieczeństwa ${ }^{92}$, to jest „działalnością rozumową” czy też, innymi słowy, z ,życiem czynnym istoty obdarzonej rozumem" 93 - świadczy poświęcenie w traktacie $O$ definicjach licznych fragmentów omawiajacych właśnie działalność rozumową człowieka. Dość wspomnieć, iż arabski filozof przedstawia definicje wielu terminów mających ścisły związek zarówno z racjonalnością, jak i z aktywnością człowieka; są to między innymi: al-'aql (intelekt, rozum), al-fi'l (działnie), al-'amal (praca), ar-rawijja (rozmyślanie, refleksja), ar-raj (pogląd, opinia), al-'ilm (wiedza), al-fahm (rozum), ad-dan (mniemanie, przypuszczenie), al-hatir (pomysł), al-isti'mal (użytek, zastosowanie), al-irada (wola), al-ma'rifa (wiedza), al-fada'il (cnoty), al-fada'il al-insanijja (cnoty ludzkie) czy też al-hikma (mądrość).

Treść traktatu $O$ definicjach ukazuje również powiązanie filozofii Alkindusa z poglądami innych, poza Arystotelesem, filozofów starożytności. Warto na przykład zauważyć, iż obecna na kartach omawianego traktatu definicja terminu ar-ridda (arab. zadowolenie) może wskazywać na oddziałanie na Alkindusa etyki stoików. Jak pisze al-Kindi, określenie ar-ridda ma wiele znaczeń, wśród których odnajdujemy również następujące: akceptowanie nie tylko tego, co człowiekowi sprawia przyjemność, lecz również stanów i wydarzeń nieprzyjemnych, przykrych ${ }^{94}$. Postulat akceptowania stanu rzeczy (arab. qana'a an-nasf ${ }^{95}$ ), bez względu na to, czy ów stan rzeczy odbieramy jako przyjemny czy nie, niewątpliwie przywodzi na myśl poglądy Zenona z Kition, Chryzypa i innych stoików głoszących konieczność wyzwolenia się mędrca spod władzy afektów. Kojarzy się on zresztą również z etyką islamską, wedle której jedną z najpiękniejszych cnót charakteryzujących człowieka wierzącego jest cierpliwość (arab. as-sabr) ${ }^{96}$.

\footnotetext{
91 Tamże.

92 Zob. Leśniak, dz. cyt., s. 83.

93 Arystoteles, Etyka nikomachejska, 1098 a 7.

94 Zob. al-Kindi, dz. cyt., s. 177.
}

95 Zob. tamże; arab. qana'a oznacza m.in.: zadowolenie, satysfakcję, a także umiar, wstrzemięźliwość.

96 Oczywiście błędem było sądzić, iż poglądy starożytnych filozofów w jakikolwiek sposób wpłynęły na etykę islamską jako taką. W czasach al-Kindiego już od około trzech-czterech pokoleń - to jest od chwili wystąpienia proroka islamu, Muhammada - stanowiła ona zamknięty system 
Nie sposób również nie dostrzec związku filozofii Alkindusa z platonizmem. Omawiajacc cnoty ludzkie al-Kindi pisze, iż łącząc pojęcie cnoty z duszą dochodzimy do wniosku, że mamy do czynienia z trzema zasadniczymi formami cnoty: mądrością (arab. al-hikma), odwagą (arab. an-nadizda) oraz umiarkowaniem, względnie cnotliwością (arab. al-'iffa) ${ }^{97}$. Rozważania te niewątpliwie przywodzą na myśl filozofię Platona wyrażoną w Państwie, zgodnie z którą idealne państwo powinno opierać się na trzech grupach (stanach): filozofach, strażnikach i robotnikach, mających realizować odrębne cele społeczne; owe trzy stany miałby być również związane z różnymi cnotami, kolejno: z mądrością, odwagą oraz umiarkowaniem.

\section{Zakończenie}

Między IX a XIV stuleciem po Chr. arabski był po prostu (między innymi) językiem nauki, pełniąc w dużej części cywilizowanego świata funkcję analogiczną do starożytnej greki czy łaciny; źródeł tej sytuacji należy poszukiwać w tzw. epoce tłumaczeń (IX stulecie po Chr.), kiedy to elity świata islamu zaczęły zapoznawać się z dorobkiem cywilizacji wcześniejszych, w tym między innymi z filozofią grecką. Język arabski stał się wówczas językiem olbrzymiego państwa, a także językiem nowej nauki, literatury etc.; wtedy to też zaczęto tworzyć arabską terminologię naukową - w tym także terminologię filozoficzną.

Na kształtującą się w owej epoce terminologię filozoficzną oddziałały główne gatunki uprawianej ówcześnie literatury: były to między innymi sam tekst Koranu, komentarze do Koranu, traktaty teologiczne etc. Dla powstania arabskiej terminologii filozoficznej kluczowy okazał się jednak wpływ tzw. literatury świeckiej, między innymi epistolografii, a także służących przede wszystkim rozrywce pierwszych dzieł beletrystycznych, nawiązujących do wzorców irańskich.

\footnotetext{
idei, opierający się na Koranie i sunnie (tj. ogólnie to ujmując: ścieżce właściwego postępowania, równoznacznego z naśladowaniem czynów proroka islamu; podstawę sunny tworzą hadisy, czyli relacje o czynach i wypowiedziach proroka Muhammada). Poglądy filozofów greckich wpłynęły wyłącznie na filozofię świata islamu; oddziałały również na pewne nurty islamskiej teologii nieortodoksyjnej, sufizm etc.

Określenie as-sabr występuje w bardzo wielu miejscach w Koranie, między innymi w surze al-'asr (zob. Koran, sura 103). Według nauczania islamu cierpliwość powinna charakteryzować życie opierające się na przekonaniu, iż w gruncie rzeczy wszelkie wydarzenia związane z życiem doczesnym - również te odbierane jako nieprzyjemne - są czymś jedynie przejściowym, zaś ostatecznie droga człowieka wierzącego w Boga prowadzi do nieskończonego szczęścia, to jest do wiecznego życia w raju.
}

97 Zob. al-Kindi, dz. cyt., s. 177. 
Tekstem niezmiernie istotnym ze względu na możliwość badania źródeł, jak również późniejszego rozwoju filozofii islamskiej - szczególnie arabskiej terminologii filozoficznej - jest traktat al-Kindiego O definicjach. Biorąc udział w tworzeniu terminologii filozoficznej w jezzyku arabskim, al-Kindi dążył do doprecyzowania znaczeń terminów poprzez poprawne ich zdefiniowanie; próbę taką podjęli zresztą później również al-Farabi i Ibn Sina (Awicenna). Kindiański traktat $O$ definicjach nie tylko zawiera omówienie określonych terminów filozoficznych, lecz również informuje - niekiedy czyniąc to nie wprost - o poglądach samego autora.

Jest wartym podkreślenia, iż na całą twórczość filozoficzną al-Kindiego w tym również na treść wspomnianego traktatu - wpłynęły zarówno elementy islamskiej tradycji religijnej, jak i filozofia grecka. Alkindus, będąc powiązanym z bardzo wówczas aktywnym środowiskiem mutazylitów, omówił w swym dziele pewną liczbę terminów wywodzących się z tradycji islamskiej - tym niemniej błędem byłoby uważać go za kolejnego teologa; przeciwnie, był on pierwszym filozofem świata islamu, o czym świadczą silniejsze związki treści traktatu $O$ definicjach z tradycją filozoficzną niż z ideami sensu stricte teologicznymi.

Na wyjątkową uwage zasługują bardzo ścisłe związki filozofii al-Kindiego z filozofią arystotelesowską - mimo iż autor traktatu $O$ definicjach nawiązuje również, w mniejszym stopniu, do etyki stoików czy też do platonizmu i neoplatonizmu. Definicje terminów takich jak „pierwsza przyczyna”, „forma”, „materia” etc. - jak również pewne koncepcje etyczne, omówione w traktacie $O$ definicjach, między innymi doktryna złotego środka - wskazują na wyraźnie powiązanie filozofii Alkindusa z poglądami Stagiryty, niewątpliwie najsilniej nań oddziałującego z filozofów greckich. 